\title{
Semiotics in the Study of Aleksander Tansman's Cultural Identity
}

\begin{abstract}
Anna Granat-Janki*
The affiliation of the Polish émigré composers with Polish culture has often raised doubts which would probably not have occurred had those composers stayed in Poland. These doubts arise from the fact that in some cases it is difficult to determine those composers cultural identity because their nationality is not that obvious. However, the composers in question never renounced their Polish identity and this fact is evident in their music. One of such composers was Aleksander Tansman (1897-1986). He was of Polish-Jewish origins and spent most of his life as an émigré in foreign lands, from 1938 being a French citizen. Although his works were not performed in Poland for a long time and were consistently neglected by music critics, the composer unambiguously defined his affiliation with Polish culture through his music. Semiotics has turned out to be a helpful tool in studying Tansman's cultural identity since his music can be perceived as a kind of cultural discourse. The composer used signs: non-musical (composer's own statements, titles, dedications, historical figure) and musical ones (quotes, musical genres, stylization, imaginative folklore, musical symbols), which have the attributes of Polishness. The aim of the paper is to prove the thesis that music may be a means of composers' cultural identification and this can be done by applying a semiotic perspective to the study.
\end{abstract}

\section{Introduction}

The affiliation of the Polish émigré composers with Polish culture has often raised doubts which would probably not have occurred had those composers stayed in Poland. These doubts arise from the fact that in some cases it is difficult to determine those composers' cultural identity because their nationality is not that obvious. ${ }^{1}$ However, the composers in question never renounced their Polish identity and this fact is evident in their music. They were aware that as émigrés they also served their country and contributed to Polish culture. The more hostile the Polish authorities and musical circles were towards them, the stronger that awareness grew. Regretfully, in their homeland Polishness was perceived as limited to the state's boundaries. ${ }^{2}$ The problem in question concerned the

"Professor, The Karol Lipiński Academy of Music in Wrocław, Poland.

1. The ethnic and cultural identity of Polish composers of Jewish descent living in the United States (including Alexandre Tansman) has been discussed by Maja Trochimczyk. [Maja Trochimczyk, "The Question of Identity: Polish-Jewish Composers in California," Polin: Studies in Polish Jewry: Polish-Jewish Relations in North America 19 (2007), 343-371.]

2. Zofia Helman, "Muzyka na obczyźnie" (Music in exile), in Między Polska a światem (Between Poland and the world), ed. Marta Fik (Warszawa: Wydawnictwo Krąg, 1992), 214; 
generation of composers born in the years 1892-1919. ${ }^{3}$ There were different reasons behind those artists' decisions to leave Poland or stay abroad and their contact with Polish government and Polish musical circles also took different course. One of such émigrés was Aleksander Tansman (1897-1986), who is the subject of this discussion (Photo 1).

Photo 1. Aleksander Tansman with a dedication to Anna Granat-Janki. Photo by Maurice Hatton

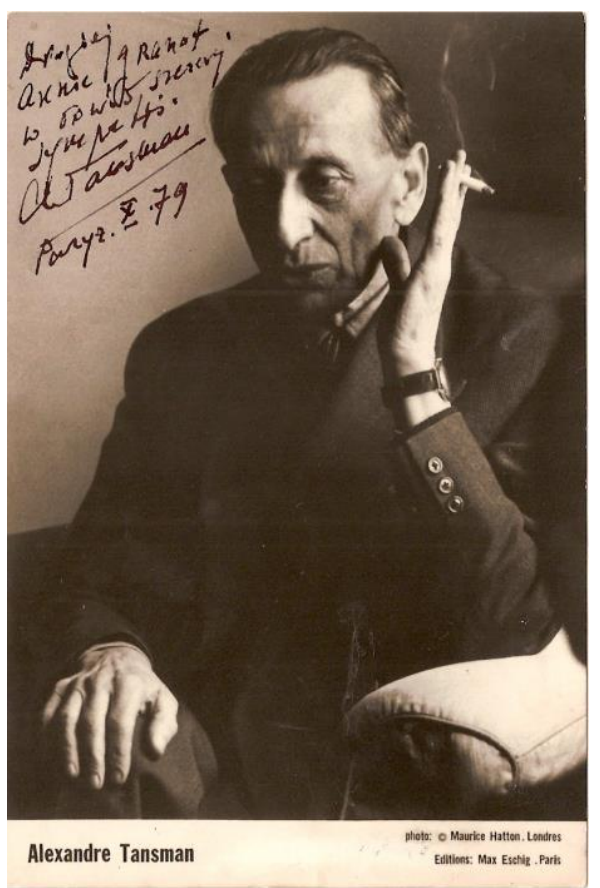

Source: Anna Granat-Janki’s private collection.

Helman, "Emigranci z wyboru" (Émigrés by choice), Polski Rocznik Muzykologiczny 8 (2010), 180-185.

3. The following composers should be mentioned here: Karol Rathaus (1895-1954), Aleksander Tansman (1897-1986), Feliks Łabuński(1892-1979), Antoni Szałowski (19071973), Michał Spisak (1914-1965), Szymon Laks (1902-1983), Jerzy Fitelberg (1903-1951), Michał Kondracki (1902-1984), Roman Maciejewski (1910-1998), Tadeusz Zygfryd Kassern (1904-1957), Roman Palester (1907-1989), Roman Haubenstock-Ramati (1919-1994), Andrzej Panufnik (1914-1991). Zofia Helman calls them "émigrés by choice;" Helman, "Muzyka na obczyźnie, 180. 


\section{Subject Literature and Methodological Concept}

The literature on Polish émigré composers and their identity includes such publications as articles of Zofia Helman, ${ }^{4}$ Maja Trochimczyk, ${ }^{5}$ a joint monograph edited by Krystyna Tarnawska-Kaczorowska. ${ }^{6}$ The issue has also been discussed in publications on individual artists, including Aleksander Tansman. Among the works devoted to the composer the following are worthy of note: the books by Janusz Cegiełła, ${ }^{7}$ Anna Granat-Janki, ${ }^{8}$ and Andrzej Wendland, ${ }^{9}$ articles by Anna Granat-Janki ${ }^{10}$ and joint monographs. ${ }^{11}$ However, in none of the above-mentioned works have the authors undertaken a comprehensive study into the problem of Aleksander Tansman's cultural identity. There have also been no attempts to analyse the problem with semiotic tools. ${ }^{12}$

4. Helman, "Muzyka na obczyźnie, 209-225; Helman, "Emigranci z wyboru, 180-185.

5. Trochimczyk, "The Question of Identity; Trochimczyk, "Exiles or Emigrants? Polish Composers in America," in East Central Europe in Exile, vol 1: Transatlantic Migrations, ed. Anna Mazurkiewicz (Cambridge: Cambridge Scholars Publishing, 2013).

6. Muzyka źle obecna [Ill-present music], parts 1 and 2, ed. Krystyna TarnawskaKaczorowska (Warszawa: ZKP, 1989).

7. Janusz Cegieła, Dziecko szcześcia, Aleksander Tansman i jego czasy (A child of luck. Aleksander Tansman and his times), vol. 1 (Warszawa: 86 Press, 1986), vol. 2 (Łódź: 86 Press, 1996).

8. Anna Granat-Janki, Forma w twórczości instrumentalnej Aleksandra Tansmana (Form in Aleksander Tansman's instrumental music) (Wrocław: Akademia Muzyczna we Wrocławiu, 1995).

9. Andrzej Wendland, Gitara w twórczości Aleksandra Tansmana (The guitar in Aleksander Tansman's music) (Łódź: Ars Longa Edition, 1996).

10. Anna Granat-Janki, "Les changements de style d'Aleksandre Tansman dans sa musique instrumentale," in Hommage au compositeur Alexandre Tansman (1897-1986), Proceedings of the international conference of November 26, 1997 in Sorbonne, texts reunited by Pierre Guillot (Sorbonne: Presses of the University of Paris, 2000), 69-84; Granat-Janki, "Tradition and Modernity in Music of Aleksander Tansman," Polish Music Journal 4, no. 1; Granat-Janki, "Valeurs et fonctions de la musique d'Alexandre Tansman" (Values and Functions of Aleksander Tansman's Music), in Music: Function and Value, vol. 2, ed. Teresa Malecka, Małgorzata Pawłowska (Akademia Muzyczna Kraków, 2013), 554568.

11. Hommage au compositeur Alexandre Tansman (1897-1986), Proceedings of the international conference of November 26, 1997 in Sorbonne, texts reunited by Pierre Guillot (Sorbonne: Presses of the University of Paris, 2000); Aleksander Tansman 1897-1986, AM Scientific Notebook in Lodz no. 25, ed. Marta Szoka (Łódź: Akademia Muzyczna, 1997).

12. Literature on music semiotics is particularly extensive. The most inspiring works in this field have been authored by Eero Tarasti and include the book Signs of Music. A Guide to Musical Semiotics (Berlin, New York: Mouton de Gruyer, 2002). 
Any deliberations on the issue of Tansman's cultural identity must begin with an overview of the composer's life. This should allow for the factors that influenced his ethnic and cultural identity to be identified.

Semiotics has turned out to be a helpful tool in studying Tansman's cultural identity since his music can be perceived as a kind of cultural discourse. The composer uses signs-codes which convey information from the sender (composer) to the receiver (listener) in an act of communication. The analytical procedure employed in this article will consist in identification of signs used by the composer and interpretation of meanings that they carry. According to the Czech semiotician and structuralist Jan Mukařovský:

Only when the full meaning has been grasped, does a work of art bespeak the author's attitude towards reality and become a call for the receiver to take their own - cognitive, emotional and volitional - stand towards reality. ${ }^{13}$

The analysis of Tansman's compositions will consist in identifying non-musical signs (composer's statements, titles, dedications, historical figures) and musical signs (quotes, musical genres, stylization, imaginative folklore, musical symbols) which are attributes of Polishness.

The discussion of non-musical signs will concentrate on a work of art as a phenomenon that exists in historical and cultural context. ${ }^{14}$ The analysis of musical signs in turn will have as its focus the elements of musical structure and the relations between them. This original method of analysis has already been presented in the article entitled "Muzyka jako dyskurs polityczny. O utworach kompozytorów polskich drugiej połowy XX wieku w perspektywie semiotycznej" (Music as discourse. The works by Polish composers of the second half of the 20th century from a semiotic perspective)..$^{15}$

13. "Dopiero wtedy kiedy ów pełny sens zostanie domknięty, staje się dzieło sztuki świadectwem stosunku twórcy do rzeczywistości i wezwaniem pod adresem odbiorcy, aby i on wobec rzeczywistości zają swoje własne stanowisko - poznawcze, emocjonalne i wolicjonalne zarazem." Jan Mukařovský, Wśród znaków i struktur. Wybór szkiców (Among signs and structures. A selection of sketches), ed. and intro. Janusz Sławiński (Warszawa: PIW, 1970), 31.

14. Mieczysław Tomaszewski, O muzyce polskiej w perspektywie intertekstualnej (Polish music form the intertextual perspective) (Akademia Muzyczna Kraków, 2005), 10.

15. Granat-Janki, "Muzyka jako dyskurs polityczny. O utworach kompozytorów polskich drugiej połowy XX wieku w perspektywie semiotycznej" (Music as political discourse. The music of Polish composers of the second half of the 20th century form the semiotic perspective), in Analiza dzieła muzycznego. Historia - theoria - praxis (Analysis of a musical work. History - theoria - praxis), vol. 2, ed. Anna Granat-Janki, Bogusław Raba, Joanna Subel, Andrzej Wolański, Agnieszka Zwierzycka (Akademia Muzyczna Wrocław, 2012), 189-202. 
The aim of the article is to validate the thesis that music may be a means of composers' cultural identification and this can be done by applying a semiotic perspective to the study.

\section{Aleksander Tansman's Life}

What was Aleksander Tansman's life like, then? He was born to an assimilated Jewish family in Łódź, Poland, in 1897. Thus, he was of Polish-Jewish descent. His mother tongue was Polish and he completed his education in Poland. He studied law at Warsaw University, took private harmony and counterpoint lessons with Piotr Rytel and attended composition classes with Henryk Melcer. In 1919 he won three first prizes at a composer's competition organised by the Polish Artistic Club in Warsaw. In spite of the success that he had achieved, Tansman left for France at the end of 1919 and settled in Paris. His decision was motivated by artistic reasons. The composer felt that he had no possibilities of further artistic development in his home country as Polish musical circles were very conservative at that time. Paris, on the other hand, was an international centre of musical life in which artists from all over the world arrived to "découvrir un climat artistique et intellectuel" of the city.

Tansman very quickly became popular in the French music market. In the 1920s and 1930s his brilliant career developed on an international scale. His successes in Paris were followed by series of concerts abroad. In the years 19271928, on the initiative of the eminent conductor Serge Koussevitzky, Tansman undertook his first tour of the United States, followed by the second one a year later (1929/1930). Between 1932 and 1933 he went on a tour around the world including the Middle and the Far East, Southeast Asia and Africa.

In the interwar period Tansman's compositions were performed by the most outstanding instrumentalists (Bronisław Huberman, Jascha Heifetz, Gregor Piatigorsky) and directed by great conductors (Arturo Toscanini, Serge Koussevitzky, Leopold Stokowski, Pierre Monteaux). His works won favour with music critics ${ }^{16}$ and became the subject of detailed studies (Raymond Petit, Irving Schwerke). ${ }^{17}$ Only in Poland, Tansman's home country, were his compositions rarely performed, ${ }^{18}$ not very favourably received $^{19}$ or went completely

16. In the interwar period Tnasmann's music was discussed in the influential French La Revue Musicale journal by such outstanding critics as: Roland-Manuel, Boris de Schloezer, André Coeuroy, Raymond Petit, Arthur Hoérée.

17. In 1929 La Revue Musicale published the monographic article "Alexandre Tansman" by Raymond Petit, and in 1931 Irving Schwerke's monograph entitled Alexandre Tansman, compositeur polonais was published.

18. After Tansman had left for Paris, there was the first concert of his music held in Warsaw in 1932. It was his piano recital. Then, in 1936 his music was presented on the 
unnoticed. ${ }^{20}$ The composer was very regretful about that, expressing his feelings in the article "O mojej twórczości muzycznej" [On my music works] published in the Muzyka journal in 1925:

My homeland is a country where my works are performed more rarely than anywhere else, the compositions that have been played on most of European and American stages have not been performed in the Philharmonic Hall; all of my works have been published abroad, none at home; Polish correspondents deliberately ignore everything that concerns my contribution to the modern trend $[\ldots] .^{21}$

The dislike for Tansman in Poland intensified sharply in the years immediately before the Second World War in connection with an increasing wave of persecutions against Jewish composers which was instigated by Goebbels in 1936 and culminated in the Entartete Musik exhibition in Düsseldorf in 1938. In that year, as a form of protest against the collaboration of the Polish government with Nazi Germany, anti-Semitism and Nazi sympathies in his home country, Tansman renounced his Polish citizenship and took French citizenship.

During the Second World War Tansman lived with his wife Colette Cras ${ }^{22}$ and two daughters - Mireille and Marianne - in Los Angeles. In 1946 he returned to France and settled in Paris, where he continued his artistic activities. After 1956 he renewed contact with Poland. His first visit to the country was connected with the 70th anniversary of his birth and took place in 1967, followed by subsequent visits in 1978, 1979 and 1980. As part of those visits concerts of his music were held. Tansman was decorated with the Medal of the Polish Composers' Union (1979), the Gold Badge of Order of Merit of the Polish People's Republic (Council of State, 1983), and the Order of Merit to Polish Culture (Minister of Culture and Art of the Polish People's Republic, 1983). Moreover, before his death, in 1986,

Polish Radio in Roman Jasiński's programme in the series "Portraits of Polish composers" and during a symphony concert in Warsaw Philharmonic Hall (the programme included Tansman's Deux Pieces pour orchestre).

19. Zdzisław Jachimecki, Muzyka polska 1986-1930 (Polish music 1986-1930), part 4 (Warszawa, 1931); Konstanty Regamey, "Muzyka polska na tle współczesnych prądów" (Polish music and modern trends), Muzyka Polska no. 7-8 (1937), 341-352; Cegiełła, Dziecko szczęścia, 302-303, 437-439, 440.

20. Konstanty Regamey, "Dwadzieścia lat muzyki w Polsce" (Twenty years of music in Poland), Muzyka Polska no. 11 (1938), 477-488. This jubilee article published on the 20th anniversary of regaining independence by Poland does not mention Tansman's name.

21. "Ojczyzna moja jest krajem, w którym dzieła moje są wykonywane rzadziej niż gdziekolwiek; utwory grane na większości estrad europejskich i amerykańskich, pozostają przez lata w Filharmonji bez wykonania; wszystkie moje dzieła są wydane zagranica, a żadne w kraju; korespondenci polscy świadomie zamilczają wszystko co dotyczy mej sytuacji w ruchu nowoczesnym [...]." Aleksander. Tansman, "O mojej twórczości muzycznej" (On my music works), Muzyka no. 4-5 (1925), 206.

22. Colette Cras was a French pianist. Tansman married her in 1937. 
he was granted (in absentia) the title of Doctor Honoris Causa by the Academy of Music in Łódź. Tansman died in Paris on the 15th of November 1986 at the age of 89 .

The overview of Tansman's life makes one realize how complex the issue of his identity is. The composer had Jewish roots and spent most of his life in France - his second homeland. At the same time, however, he was a Pole. There were strong ties that connected him with Polish culture - something he frequently emphasized in his statements. He always considered himself a Polish composer and that was how he was perceived by musicologists, the confirmation of which is the monograph Alexandre Tansman, compositeur polonais by Irving Schwerke. ${ }^{23}$ Although his works were not performed in Poland for a long time and were consistently ignored by music critics, ${ }^{24}$ the composer unambiguously stated his affiliation with Polish culture through his music.

The works which draw on the traditions of Polish culture constitute a significant part of Tansman's oeuvre. The research material gathered by the author for the purpose of this study consists of 28 works including collections of more than ten miniatures. They have been analysed in terms connections with Polish culture. The discussion of the results of the author's analyses will include non-musical and musical attributes of Polishness.

\section{Non-Musical Attributes of Polishness}

The starting point for the discussion of Tansman's connections with Polish culture are the composer's own statements. He repeatedly expressed his opinion on that matter. From his many statements, it is worth quoting the one that he made during the interview conducted by Janusz Cegieła in 1971. Tansman admitted that:

We cannot expunge childhood and teenage years, cultural traditions and the memory of the surroundings where we grew up from our lives. Volens nolens,

23. Irving Schwerke, Alexandre Tansman compositeur polonaise (Paris: Editions Max Eschig, 1931).

24. The situation started to change in 1977 when Ruch Muzyczny published three articles by Andrzej Zieliński ["Klasyk polskiej muzyki współczesnej" (The classic of Polish modern music)], Zofia Helman ["Estetyka twórczości Aleksandra Tansmana" (Aesthetics of Aleksander Tansman's music)] and Tadeusz Kaczyński ["Między Polską a Francją" (Between Poland and France)]. Then in 1995 Anna Granat-Janki's book Forma w twórczości instrumentalnej Aleksandra Tanamsna (Form in Aleksander Tansman's instrumental music) was published, followed in 1996 by the two-volume monograph Dziecko szczęścia, Aleksander Tansman $i$ jego czasy (A child of luck. Aleksander Tansman and his times) (the first volume was published in 1986) and the book Gitara w twórczości Aleksandra Tansmana (The guitar in Aleksander Tansman's music) by Andrzej Wendland. 
whether my music is known in my home country or not, I belong to the Polish culture. I am a citizen of France [...], but it does not change my artistic affiliation which has always manifested itself in my music - since the very beginning to the present day. ${ }^{25}$

Earlier, in 1948, in his book on his friend Igor Stravinsky, Tansman expressed his view on artists' national identification. In his opinion, national identity does not result only from the presence of forms and genres typical of folk music in a given composer's oeuvre, but is determined by the composer's relation with the musical tradition of a particular country. ${ }^{26}$ Undoubtedly, Tansman felt emotionally connected with Poland, he was interested in Polish affairs, followed attentively the events happening in his home country and protested against various forms of political violence.

A title is a special type of sign which, together with the reference to its object, creates a communicative situation, broadly conceived. ${ }^{27}$ According to Stownik terminów literackich (Dictionary of literary terms) a title is a name given to a work by its author, it is an integral part of the work's text and its first distinct section..$^{28}$ It fulfils two major functions: identifying (signifying) one and informative (semantic) one, and additionally it serves an evocative function.

The titles of Tansman's compositions allow for those works to be unambiguously identified with Polish culture. The following titles should be mentioned in the first place: Rapsodie polonaise, Quatre danses polonaises and Suite in modo polonico. They all include the adjective "Polish." In those cases the title serves an informative and identifying function, forming multiple connections with the content of the work that it names and symbolizes. This is exemplified by Four Polish Dances which include: polka (1st movement), kujawiak (2nd movement), dumka (3rd movement) and oberek (4th movement). Thus, the composition employs two Polish national dances: kujawiak and oberek, which originate in folk music (Example 1).

25. "Nie można wykreślić z życia lat dziecięcych i młodzieńczych, tradycji kulturalnych, pamięci otoczenia, w którym się wzrastało. Volens nolens, czy moja muzyka jest w kraju znana czy nie, należę do kultury polskiej. Jestem obywatelem Francji [...], ale nie zmienia to bynajmniej mojej przynależności artystycznej, która zresztą dawała i daje nadal o sobie znać w całej mojej twórczości - od początku aż do chwili obecnej." Cegiełła, "Aleksander Tansman," in Szkice do autoportretu polskiej muzyki wspótczesnej (Sketches for the self-portrait of Polish contemporary music) (Kraków: PWM, 1979), 61.

26. Alexandre Tansman, Igor Stravinsky (Paris: Amiot-Dumont, 1948), 63.

27. The functions that a title of a musical work may serve are discussed by Hanna Kostrzewska. [Hanna Kostrzewska, "Funkcje tytułu dzieła muzycznego" (The functions of a work of music's title), in Dzieło muzyczne i jego funkcje (Work of music and its functions), ed. Anna Nowak (Bydgoszcz: Akademia Muzyczna, 2010), 69-82.]

28. "Tytul" (Title), in Stownik terminów literackich (Dictionray of literary terms), ed. Janusz Sławiński (Wrocław: Ossolineum, 2000), 596. 
Example 1. A. Tansman, Quatre danses polonaises for orchestra, 2nd movement: Kujawiak

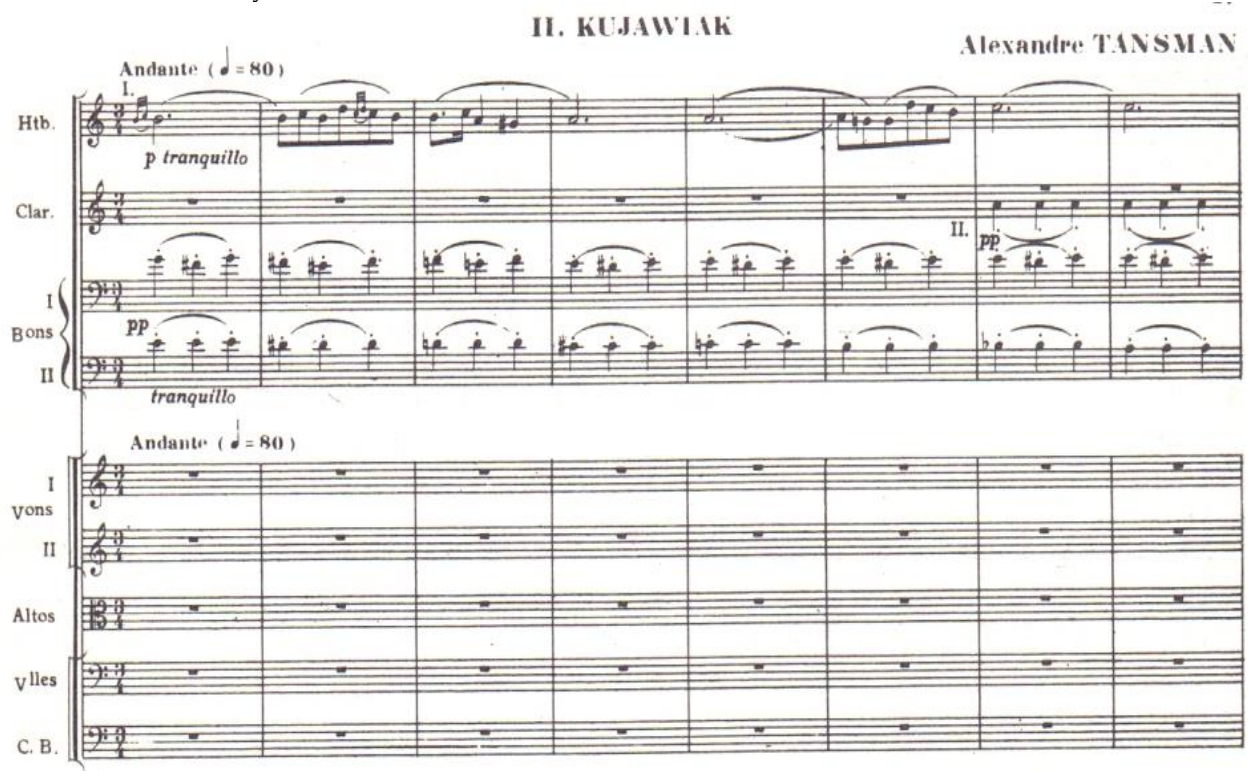

Source: Editions Max Eschig, 1932. A. Granat-Janki's private collection.

In another composition - Polish Rhapsody - the title refers to those fragments of the piece where the expressive character has been determined by various tempo markings, such as Tempo di polonaise, Tempo di mazurka, Tempo di mazur, which are typical tempos of Polish folk dances. The title Suite in modo polonico, in turn, corresponds to the 7th movement of the composition - Alla polacca, where the expressive character of music is defined by the name. In all of the abovementioned compositions the titles additionally serve an evocative function and thus trigger an emotional reaction in the listener.

Another type of verbal signs that can be found in Tansman's scores are dedications. They are addressed to the Poles with whom composer was bound by ties of friendship. Among them there are performers and conductors who had his works in their repertoire. Suite dans le style ancien (1929) was composed for the pianist Karol Szreter, Symphonie No 5 en ré (1942) - for the conductor and composer Paweł Klecki, and Sinfonietta No 2 (1977) - for the conductor Renard Czajkowski. The collection of piano miniatures entitled Album d'amis is a kind of gift for friends. The third miniature was dedicated by Tansman to his biographer Janusz Cegiełła, and the sixth one - to the musicologist Tadeusz A. Zieliński. On the pages of Tansman's scores one may find names of outstanding figures of the musical world, such as: the pianist Arthur Rubinstein (Quatre prelude, 4th movt. [1921], Étude-scherzo [1922], Sonate No. 2 [1928]), the pianist Ignacy Jan Paderewski (Vingt pièces facile sur des mélodie populaires polonaises [1924]), the harpsichordist Wanda Landowska (Polonaise, 1935) or the composer Karol Szymanowski (Quatre préludes, 6th movt. [1921]). Some of the dedications are related to painful events in 
Polish history, for example Polish Rhapsody (1940) is dedicated to the defenders of Warsaw during the Second World War.

Non-musical signs also include outstanding figures in Polish history and culture. They serve the function of national symbols. The signs of this type are deeply rooted in a given nation and they represent its social power. Their role is to express and consolidate national identity. ${ }^{29}$

The following figures were chosen by Tansman as national symbols: Lech Wałęsa - the politician and founder of the Solidarity Movement who contributed to the fall of communism in Poland, the national composer Fryderyk Chopin and the great pianist Arthur Rubinstein. The composer paid them a tribute in his works: Hommage à Lech Walesa, Hommage à Chopin and Hommage à Arthur Rubinstein (Example 2).

\section{Example 2. A. Tansman, Hommage à Lech Walesa for guitar, p. 1}

\section{Hommage à Leeh Walesa}

Alexandre TANSMAN

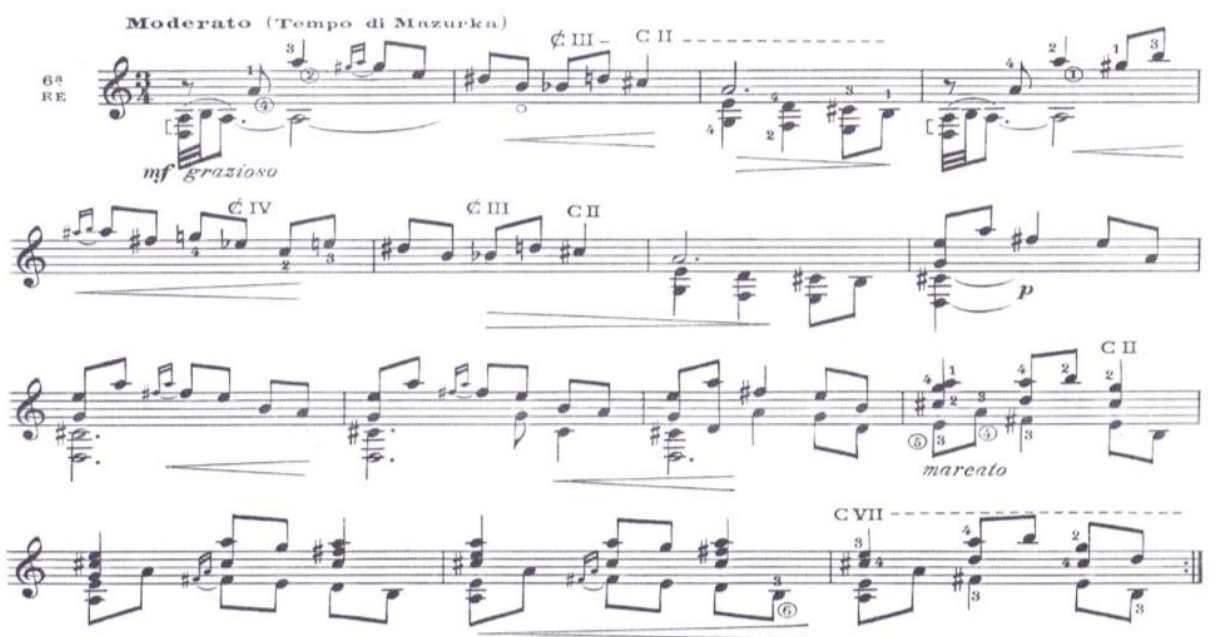

Source: Editions Max Eschig, 1982. A. Granat-Janki's private collection.

29. Michael E. Geisler, National Symbols, Fractured Identities. Contesting the National Narrative (Middlebury, 2005), 15. 


\section{Musical Attributes of Polishness}

In the process of semiotisation of music an important role is played by quotations. According to the Polish musicologist Mieczysław Tomaszewski, a quotation in the literal sense means:

[...] quoting someone else's music in one's own composition in a fully intentional and overt manner, that is in a way that marks it out and makes it easier for the listener to identify and understand the aim and meaning of the quotation. ${ }^{30}$

An exact quotation serves its function by evoking certain sentimental, symbolic, ideological or patriotic associations.

In Tansman's case quotation is connected with the composer's identification with the Polish nation and culture. He has manifested his ethnic and cultural affiliations especially in Rapsodie polonaise (1940). In the movement marked as Tempo di mazurka he quoted the Polish national anthem - Jeszcze Polska nie zginęta (Poland is not yet lost) (Dąbrowski's Mazurka).

The quotation of the national anthem - the symbol of the Polish state - in a composition dedicated to "the defenders of Warsaw" ("aux defenseurs de Varsovie") who in 1939 fought for the capital against Nazi invaders has a symbolic and patriotic meaning. The composer refers to the tempo and rhythm of a mazurka which is a Polish national dance. In the national anthem the melody quoted by Tansman is accompanied by the words: "Poland has not yet perished, so long as we still live. What the alien force has taken from us, we shall retrieve with a sabre," 31 and because of that it evokes associations with national sovereignty and independence.

In another two compositions Tansman quoted Polish folk tunes which he remembered from childhood. In Scherzetto popularesco - the second movement of Sinfonietta No 2 (1978) - he used quotations of three popular folk songs: Umart Maciek umart (Died, Maciek has died), Krakowiaczek jeden (A man from Cracow) and Wlazt kotek na płotek (A kitten climbed the fence).

The composition Vingt pièces facile sur des mélodie populaires polonaises (1924) in turn - in keeping with its title - includes quotations of such popular Polish tunes as Umart Maciek umart (Died, Maciek has died), Wlazł kotek na płotek (A kitten climbed

30. "[...] przytoczenie w utworze własnym muzyki cudzej dokonane po pierwsze w pełni świadomie, po drugie zaś w pełni jawnie, czyli uczynione w sposób wyróżniony, ułatwiający słuchaczowi identyfikacje i rozumienie celu i sensu tego przytoczenia." Tomaszewski, Muzyka Chopina na nowo odczytana (Chopin's music rediscovered) (Kraków: Akademia Muzyczna, 1996), 117. Quoted after: Bogumiła Mika, Sposoby użycia cytatu muzycznego jako strategia interstylistyczna (The use of musical quotation as an interstylistic strategy). Retrieved from https://ces.to/X1e5tl.

31. "Poland is not yet lost," in Wikipedia. The Free Encyklopedia. Retrieved from https://ces.to/9tTjr6. 
the fence) and the religious song Boże coś Polskę (God save Poland). This last song is strongly related to the history of the Polish state. Up until 1918 it was considered an unofficial anthem of independent Poland and even today the audiences customarily stand up when this song is performed, just as in the case of the national anthem.

Also musical genres are the signs that testify to Tansman's affiliation with Polish culture. The composer employed folk dance genres. He often used a stylized mazurka dance, that is an artistic arrangement combining three Polish folk dances: mazurka, kujawiak and oberek. The ideal model of this genre in piano music was developed by Fryderyk Chopin and it was to this composer that Tansman referred to when he was composing his four series of Mazurkas for piano (Example 3). He started working on those pieces in 1918 and altogether he composed 36 mazurkas collected in four volumes published in the years: 1929 - the first volume, 1932 - the second, 1941 - the third and fourth volumes. It was not the original folk dance that became the starting point for Tansman's work. The composer had no direct contact with Polish folk music. He drew his notion of Polish folklore from Chopin's stylized compositions. When discussing Tansman's mazurkas one should consider the means of stylization that he used. Following Chopin's example, he stylized all dances of the mazurka type: the mazurka itself, the kujawiak and the oberek, preserving their fundamental features (rhythm, metre, tempo and expressive character). The melodic lines of his works are based on major and minor scales as well as modal scales, especially the Lydian mode, which he considered the most typical scale of Polish folklore determining the specific sound of Polish folk music. ${ }^{32}$ He uses a drone of a fifth in the bass to imitate the sound of the basolia being tuned up in a folk music band and the tempo and rhythmic patterns typical of the above-mentioned mazurka-type dances. What definitely differs Tansman's mazurkas from Chopin's is the harmony. The mixed range of harmonic structures used by the composer includes: major, minor and quartal chords, secondal harmony, bitonality and structures of purely sonic qualities, such as series of parallel chords. ${ }^{33}$

32. Alain Jomy and Catherine Ravet's radio programme, Portrait d'Alexandre Tansman, part 1, Radio France, Paris, 21 February 1985.

33. On Tansman's mazurkas and inspiration by folk music, see Granat-Janki, "Forma w twórczości instrumentalnej, and Granat-Janki, "Les changements de style d'Aleksandre Tansman, 76 . 
Example 3. A. Tansman, Mazurkas for piano, volume 1 (1918-1928), Mazurka no. 1 -Oberek (fragment), p. 1

\section{RECUEIL DE MAZURKAS}

(1918-1928)

\section{Alexandre TANSMAN}

No 1 (Oberek)
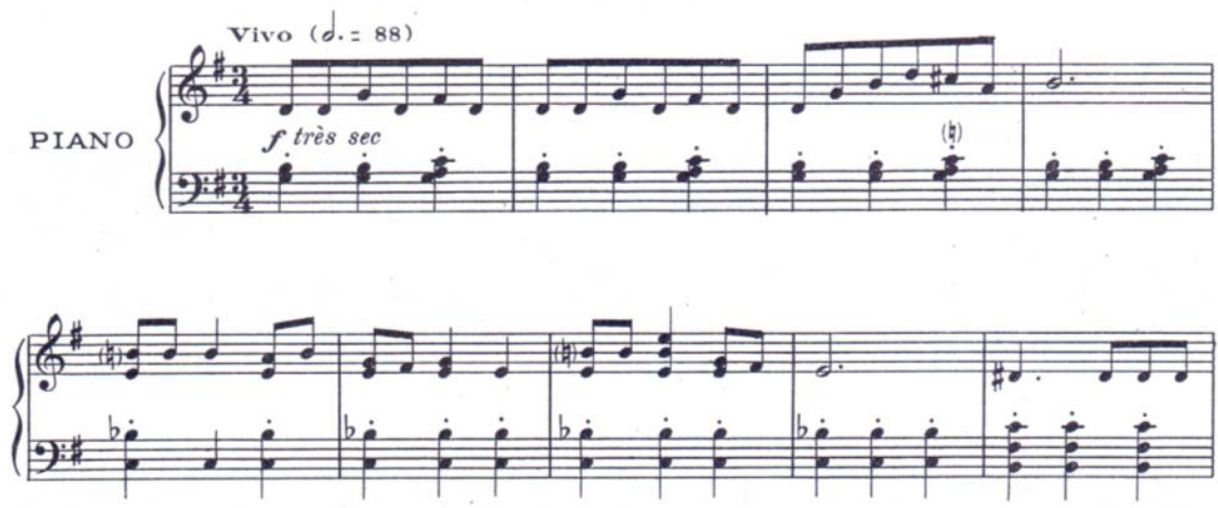

Source: Editions Max Eschig, 1929. A. Granat-Janki's private collection.

It should be noticed that the rhythmic patterns of the mazurka type were particularly close to the composer's heart, from the first mazurkas that can probably be dated to 1915 to the ones composed in the evening of life, such as Album d'amis from 1980 (3rd movt. Tempo di Mazur), Hommage à Lech Walesa from 1982 (Tempo di Mazurka) or Alla Polacca from 1985, which closes his oeuvre.

It is worth mentioning that Tansman stylised Polish folk dances not only in the series of piano Mazurkas. The kujawiak and the oberek can also be found in his Suite in modo polonico (3rd movt. - Kujawiak, 9th movt. - Oberek), while the polonaise is included in such compositions as Rapsodie polonaise (2nd movt. - Tempo do polonaise), Suite in modo polonico (4th movt.) and Sérénade No. 2 for violin, viola and cello (4th movt.: Danse Polonaise).

By stylizing folk music the composer draws the listener's attention to those elements of music which evoke Polish folklore in the genres that originate in folk dance music. Similar techniques were used by Tansman in other instrumental music genres. In the final (third) movement of his Triptych for string quartet he employs the interval of an augmented fourth to construct the melody and pedal points or drones of fifths in the accompaniment, thereby evoking the atmosphere of folk music. He uses similar elements in the third movement of his String Quartet No. 6. Its triple metre, the shape of the melodic line played by the first violin with the tritone as a structural element, long sustained drones and a specific expressive character point to Polish folklore as the source of inspiration. In this case it is specifically highlanders' music which Tansman knew thanks to another Polish national composer - Karol Szymanowski. 
One should remember, however, that Tansman often approached folk music intuitively, and thus in his compositions he presented his own view of it. Such an approach is described as imaginative folklore. For Tansman Polish music was a synthesis of melancholy and exuberance, ${ }^{34}$ which were epitomised in dances such as polonaise, oberek and kujawiak. This music is also characterised by a specific mood, which in the case of Chopin's works was described as "sorrowful." Tansman claimed that the Polish character of his music can be noticed even in his last compositions.

Musical symbols are signs with strong semantic charge. The most important of them is the music of the Polish national composer Fryderyk Chopin. When analysing Tansman's works one is bound to notice Chopin's influence. Even a cursory glance at the catalogue of Tansman's piano compositions calls up associations with Chopin's music. ${ }^{35}$ Apart from 36 mazurkas he also composed three ballads, four nocturnes, five impromptus, a number of preludes and two works in memory of Chopin: Tombeau de Chopin for string orchestra and Hommage à Chopin for guitar, in which he stylized the genres typical of Chopin's music (nocturnes, preludes, waltzes and mazurkas). Moreover, he also used in his compositions such markings as Mazurka "à la Chopin" (3rd movt. of Quatre Danses Miniatures) or Intermezzo Chopiniano (2nd movt. of Concertino pour piano), which suggest to the performers that the pieces should have Chopinian character. The Polish national composer played a significant role in the part of Tansman's music that can be described as national and folkloristic. The references to Chopin proved that Tansman upheld the values that his music represented. The composer of mazurkas and polonaises was a symbol of Polishness, "the Soul of Poland."36 By referring to his music Tansman emphasized his own affiliation with Polish culture and its fundamental values (Example 4).

34. Tadeusz Kaczyński, "Rozmowa z Aleksandrem Tansmanem" (Interview with Aleksander Tansman), Ruch Muzyczny no. 20 (1973), 5.

35. On the connection between Tansman's and Chopin's music, see Kaczyński, "Między Polską a Francją" (Between Poland and France), Ruch Muzyczny no. 13 (1977), 6-7. Cf. Granat-Janki, "Valeurs et fonctions de la musique, 561-562 and Granat-Janki, "Tradition and Modernity in Music.

36. Alicja Jarzębska, Spór o piękno muzyki. Wprowadzenie do kultury muzycznej XX wieku (A dispute over beauty of music. Introduction to music culture of the 20th century) Wrocław: Wydawnictwo Uniwersytetu Wrocławskiego, 2004), 122. 
Example 4. A. Tansman, Tombeau de Chopin for String Orchestra, p. 1

TOMBEAU de CHOPIN

(for Shing Quintet or Shing Orchesha*)

1. NOCTUR N

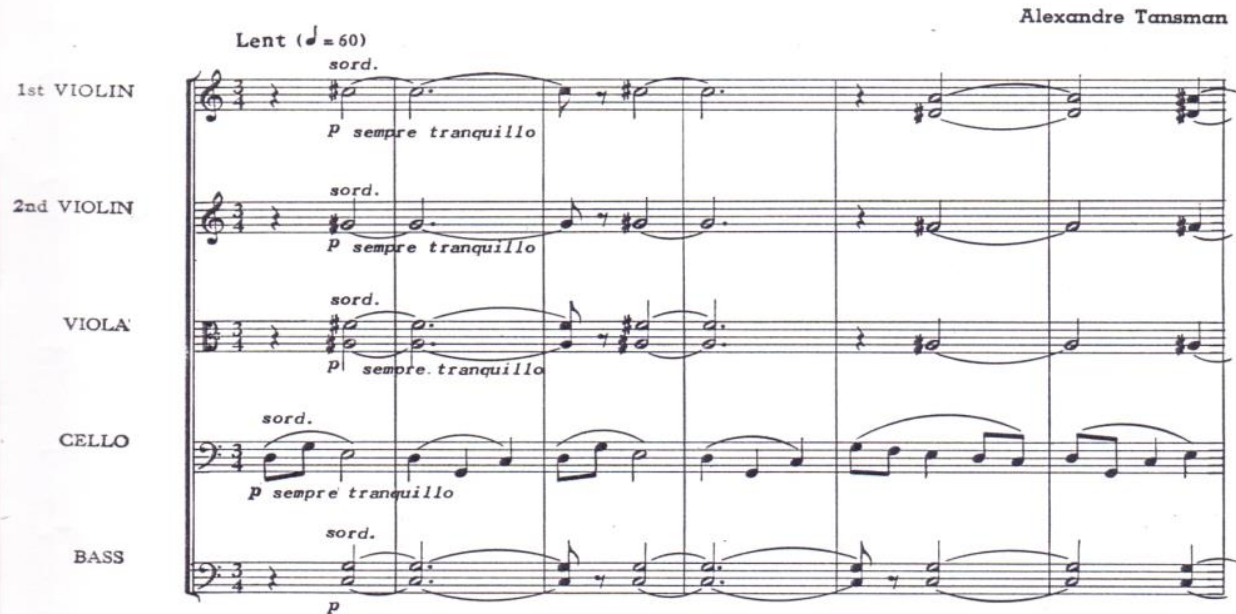

Source: Leeds Music Corporation, 1951. A. Granat-Janki’s private collection.

Another elements that also grow into musical symbols are the quotation of the national anthem in Polish Rhapsody and the stylization of Polish folk music that have been discussed above.

\section{Conclusion}

The study of Tansman's oeuvre in which the semiotic perspective was employed has proven that throughout his whole life the Polish émigré composer identified himself with the Polish culture through his music. Poland was particularly close to his heart, which he confirmed in the foreword to the book Dziecko szczęścia, Aleksander Tansman i jego czasy (A child of luck. Aleksander Tansman and his times) by Janusz Cegielła:

Of course I owe much to France, but no one who has ever listened to my music can have any doubts as to the fact that I have always been and will always be a Polish composer. ${ }^{37}$

Thus, for the composer of not only Polish but also Jewish descent, of Polish and French nationality, the Polish culture came to be the main focus of interest. He

37. "Oczywiście wiele zawdzięczam Francji, ale nikt, kto kiedykolwiek słyszał moje utwory, nie może mieć wątpliwości, że byłem, jestem i na zawsze pozostanę kompozytorem polskim." Tansman’s written statement from 1983. Cegiełła, Dziecko szczęścia, 5. 
composed pieces that were perceived as Polish not only by Poles but also by foreign listeners who easily identified them with the Polish nation. Aleksander Tansman was an ambassador of Polish culture to the world although for many years his music was underestimated in Poland and was not performed due to the composer's Jewish origins or because of the Polish state's cultural policy. The use of semiotic tools in the study allowed for the essence of Tansman's music to be identified. It lies in the meanings and senses that his works have been invested with from the perspective of Polish history and culture.

\section{Bibliography}

Aleksander Tansman 1897-1986. AM Scientific Notebook in Lodz no. 25, edited by Marta Szoka. Łódź: Akademia Muzyczna, 1997.

Cegiełła, Janusz. Dziecko szczęścia, Aleksander Tansman i jego czasy (A child of luck. Aleksander Tansman and his times), vol. 1. Warszawa: 86 Press, 1986, vol. 2. Łódź: 86 Press, 1996.

. "Aleksander Tansman." In Szkice do autoportretu polskiej muzyki wspótczesnej (Sketches for the self-portrait of Polish contemporary music). Kraków: PWM, 1979), 60-69.

Geisler, Michael E. National Symbols, Fractured Identities. Contesting the National Narrative. Middlebury, 2005.

Granat-Janki, Anna. "Valeurs et fonctions de la musique d'Alexandre Tansman" (Values and Functions of Aleksander Tansman's Music). In Music: Function and Value, vol. 2, edited by Teresa Malecka, Małgorzata Pawłowska, 554-568. Akademia Muzyczna Kraków, 2013.

"Muzyka jako dyskurs polityczny. O utworach kompozytorów polskich drugiej połowy XX wieku w perspektywie semiotycznej" (Music as political discourse. The music of Polish composers of the second half of the 20th century form the semiotic perspective). In Analiza dzieła muzycznego. Historia - theoria - praxis (Analysis of a musical work. History - theoria - praxis), vol. 2, edited by Anna Granat-Janki, Bogusław Raba, Joanna Subel, Andrzej Wolański, Agnieszka Zwierzycka, 189-202. Akademia Muzyczna Wrocław, 2012.

"Les changements de style d'Aleksandre Tansman dans sa musique instrumentale." In Hommage au compositeur Alexandre Tansman (1897-1986). Proceedings of the international conference of November 26, 1997 in Sorbonne, texts reunited by Pierre Guillot, 69-84. Sorbonne: Presses of the University of Paris, 2000. 

Forma w twórczości instrumentalnej Aleksandra Tansmana (Form in Aleksander Tansman's instrumental music). Wrocław: Akademia Muzyczna we Wrocławiu, 1995.

_. "Tradition and Modernity in Music of Aleksander Tansman." Polish Music Journal 4, no. 1 .

Helman, Zofia. "Emigranci z wyboru" (Émigrés by choice). Polski Rocznik Muzykologiczny 8 (2010), 180-185.

Helman, Zofia. "Muzyka na obczyźnie" (Music in exile). In Między Polska a światem (Between Poland and the world), edited by Marta Fik. Warszawa: Wydawnictwo Krąg, 1992.

Hommage au compositeur Alexandre Tansman (1897-1986). Proceedings of the international conference of November 26, 1997 in Sorbonne, texts reunited by Pierre Guillot. Sorbonne: Presses of the University of Paris, 2000.

Jachimecki, Zdzisław. Muzyka polska 1986-1930 (Polish music 1986-1930), part 4. Warszawa, 1931.

Jarzębska, Alicja. Spór o piękno muzyki. Wprowadzenie do kultury muzycznej XX wieku (A dispute over beauty of music. Introduction to music culture of the 20th century). Wrocław: Wydawnictwo Uniwersytetu Wrocławskiego, 2004.

Kaczyński, Tadeusz. "Między Polską a Francją" (Between Poland and France). Ruch Muzyczny no. 13 (1977), 6-7.

. "Rozmowa z Aleksandrem Tansmanem" (Interview with Aleksander Tansman). Ruch Muzyczny no. 20 (1973), 3-5.

Kostrzewska, Hanna. "Funkcje tytułu dzieła muzycznego" (The functions of a work of music's title). In Dzieto muzyczne i jego funkcje (Work of music and its functions), edited by Anna Nowak, 69-82. Bydgoszcz: Akademia Muzyczna, 2010.

Mukařovský, Jan. Wśród znaków i struktur. Wybór szkiców (Among signs and structures. A selection of sketches), edited and introduction by Janusz Sławiński. Warszawa: PIW, 1970.

Muzyka źle obecna [Ill-present music], parts 1 and 2, edited by Krystyna Tarnawska-Kaczorowska. Warszawa: ZKP, 1989.

Regamey, Konstanty. "Dwadzieścia lat muzyki w Polsce" (Twenty years of music in Poland). Muzyka Polska no. 11 (1938), 477-488.

_. "Muzyka polska na tle współczesnych prądów" (Polish music and modern trends). Muzyka Polska no. 7-8 (1937), 341-352;

Schwerke, Irving. Alexandre Tansman compositeur polonaise. Paris: Editions Max Eschig, 1931.

Tansman, Alexandre. Igor Stravinsky. Paris: Amiot-Dumont, 1948.

_. "O mojej twórczości muzycznej" (On my music works). Muzyka no. 4-5 (1925), 206.

Tarasti, Eero. Signs of Music. A Guide to Musical Semiotics. Berlin, New York: Mouton de Gruyer, 2002. 
Tomaszewski, Mieczysław. O muzyce polskiej w perspektywie intertekstualnej (Polish music form the intertextual perspective). Akademia Muzyczna Kraków, 2005.

_. Muzyka Chopina na nowo odczytana (Chopin's music rediscovered). Kraków: Akademia Muzyczna, 1996.

Trochimczyk, Maja. "Exiles or Emigrants? Polish Composers in America." In East Central Europe in Exile, vol 1: Transatlantic Migrations, edited by Anna Mazurkiewicz. Cambridge: Cambridge Scholars Publishing, 2013.

_. "The Question of Identity: Polish-Jewish Composers in California." Polin: Studies in Polish Jewry: Polish-Jewish Relations in North America 19 (2007), 343371.

"Tytuł" (Title). In Słownik terminów literackich (Dictionray of literary terms), edited by Janusz Sławiński. Wrocław: Ossolineum, 2000.

Wendland, Andrzej. Gitara w twórczości Aleksandra Tansmana (The guitar in Aleksander Tansman's music). Łódź: Ars Longa Edition, 1996. 